\title{
ANALYSIS OF LANDSCAPE QUALITY IN THE QUEIMA-PÉ RIVER BASIN, MATO GROSSO
}

\author{
Rogerio Gonçalves Lacerda de Gouveia ${ }^{1}$, Edinéia Aparecida dos Santos Galvanin ${ }^{2}$, \\ Sandra Mara Alves da Silva Neves ${ }^{3}$, Jesã Pereira Kreitlow ${ }^{4}$, Anthero Luiz dos Santos ${ }^{5}$ \\ ${ }^{1}$ University of Uberaba, Environmental Engineering Department, Uberlândia, Minas Gerais, Brasil - rglgouveia@ gmail.com \\ ${ }^{2}$ University of the State of Mato Grosso, Department of Mathematics, Barra do Bugres, Mato Grosso, Brasil - galvanin@ gmail.com \\ ${ }^{3}$ University of the State of Mato Grosso, Department of Geography, Cáceres, Mato Grosso, Brasil - ssneves@unemat.br \\ ${ }^{4}$ University of the State of Mato Grosso, Gratuate in Environment and Agricultural Production Systems, Tangará da Serra, Mato \\ Grosso, Brasil - jesapk1@ hotmail.com \\ ${ }^{5}$ Environment Secretariat, Tangará da Serra, Mato Grosso, Brasil - anthero@tangaradaserra.mt.gov.br
}

Received for publication: 17/03/2014 - Accepted for publication: 03/07/2014

\begin{abstract}
In thist study, land use and landscape quality were analyzed in the Queima-Pé river basin, Mato Grosso, Brazil. Land use and landscape quality were identified based on $3 \mathrm{~m}$ of spatial resolution images from GeoEye. For land use, manual segmentation and visual interpretation methods were used. Twelve map classes were identified and semi-perennial crops, temporary crops, pasture and native vegetation were the most significant ones. In terms of land use, the basin area contained $55.83 \%$ pasture, $26.06 \%$ crops, and $7.49 \%$ natural vegetation. Landscape analysis revealed that the study area contained $0.79 \%$ lower class, $87.80 \%$ medium-class, and $11.40 \%$ upper-class quality landscape. Through this analysis was determined predominance of the visual quality characterized as medium class, in the basin area.

Keywords: Geotechnology; land use; environment.
\end{abstract}

\section{Resumo}

Análise da qualidade da paisagem na bacia do rio Queima-Pé, Mato Grosso. Este trabalho tem como objetivo analisar o uso da terra e a qualidade da paisagem na bacia hidrográfica do rio Queima-Pé, Mato Grosso, Brasil. Foram utilizadas imagens de $3 \mathrm{~m}$ de resolução espacial do satélite GeoEye para elaboração do mapa de uso da terra e de qualidade da paisagem. Para a elaboração do mapa de uso da terra foi utilizada a segmentação manual e interpretação visual. Foram mapeadas doze classes temáticas, sendo as mais expressivas a lavoura semiperene, lavoura temporária, pastagem e vegetação natural. A pastagem está presente em $55,83 \%$ da área, as lavouras em $26,06 \%$ e a vegetação natural em 7,49\% da área da bacia. A análise da paisagem permitiu verificar que a classe baixa qualidade da paisagem está presente em $0,79 \%$ da área da bacia, a classe média em 87,80\% e a classe alta em $11,40 \%$ da área de estudo. Através desta análise verificou-se a predominância da qualidade visual caracterizada como média na bacia.

Palavras-chave: Geotecnologias; uso da terra; meio ambiente.

\section{INTRODUCTION}

Studies on landscape are considered an important resource for environmental issues, since they reveal the way geographical space is shaped in function of landscape types and their use. (BERTRAND, 1971).

Landscape types may be divided into natural original landscapes and altered landscapes. In the first case, levels of human interference are minimum. Natural altered landscapes consist in transformation of the primitive forest in mature secondary forest or landscapes with urban influence, farming and mining, turning the ecosystem unstable as a reaction to the new biotope conditions (OLIVEIRA, 1983).

FLORESTA, Curitiba, PR, v. 45, n. 1, p. 21 - 30, jan. / mar. 2015.

Gouveia, R. G. L. de. et al.

ISSN eletrônico 1982-4688 / ISSN impresso 0015-3826 
These new biotope conditions are related to the grade of anthropization that this landscape presents. Highly anthropized landscapes present great number of artificial elements introduced in nature by human action resulting in negative impacts, like poor visual quality (LIMA et al, 2004).

According to Périco and Cemin (2006), composition of landscape is a sum of natural influences and of human actions in a determined period. Thus, the study of alterations occurred over time gives supports to localization and identification of environmental risks. This way, evaluation of landscape is of fundamental importance to diagnose current problems, estimate future influences and point out necessary changes to preserve natural balance.

In this context, remote sensory analysis allows fast monitoring of geographical changes, turning out to be one of the most important tools to detect alterations in the landscape of a determined region, without high costs. (GOMES et al., 2012).

Queima-Pé river basin, object of this study, was chosen because of its great importance for the municipality of Tangará da Serra, both for water capitation to supply urban population and for integrating the Sepotuba river basin system, which is part of the Bacia (Basin) do Alto Paraguai (BAP).

In view of the above, this work aimed to analyze the land use and landscape quality in the Queima-Pé basin region.

\section{MATERIAL AND METHODS}

\section{Study area}

Queima-Pé river basin is located in the western central region of Brazil, medium north of the Mato Grosso state, with a total area of $15,684.24$ hectares, between the geographical coordinates $14^{\circ} 33^{\prime}$ to $14^{\circ} 43^{\prime}$ South latitude and $57^{\circ} 37^{\prime}$ to $57^{\circ} 28$ West longitude, within the limits of the municipality of Tangará da Serra (Figure 1).

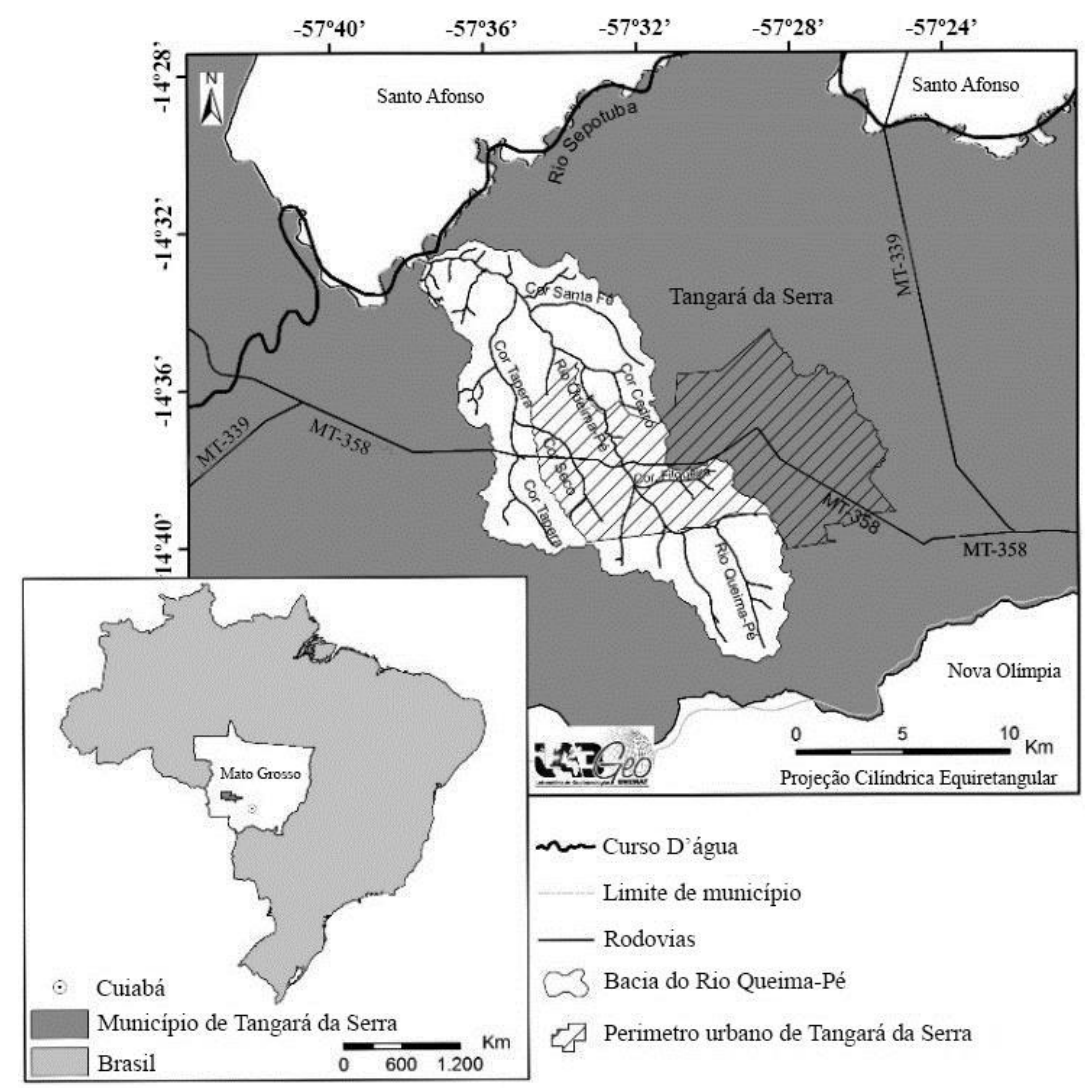

Figure 1. Location of study area.

Figura 1. Localização da área de estudo. 
According to Köppen system, climate of the region is Tropical wet-dry (AW). The average annual temperature values, rainfall and relative humidity are respectively $24.4{ }^{\circ} \mathrm{C}, 1,500 \mathrm{~mm}$ and $70-$ $80 \%$ (DALLACORT et al., 2010). Mountains and highlands of Tapirapuã characterize the landscape, being $2 \%$ mountainous, $3 \%$ hilly and $95 \%$ flat (BRASIL, 1982).

Soil classes found in the basin are dark dystrophic Red Latosol, dystroferric Red Latosol, euthroferric Red Latosol and dystrophic Red-yellow Acrisol (BRASIL, 1997). Access to the area is through highways MT-358, MT-399, MT-339.

Phyto-ecological region typical of the basin is composed by semi-deciduous seasonal forest and arborized savanna (cerrado), according to Radam Brasil (BRASIL, 1982).

\section{Materials}

Orthorectified images from Geoeye satellite, referred to the bandwidths po 772471-00, po 772471-10, and po 772471-20, with an 8-bit radiometric resolution, were used. Images used were taken in august 2011 (dry season), with 3m spatial resolution and WGS 84 datum.

Vector delimitation of the hydrographic basin limits of the Queima-Pé river, was made automatically through ArcGis 9.2 software. Topographical data of the Digital Elevation Model (DEM), in raster format, were collected from the Brazilian geomorphometric database of the project TOPODATA, supplied by the Instituto Nacional de Pesquisa (INPE), (2010).

Field works were conducted using a Global Positioning System (GPS) navigation device and digital camera. ArcGis version 9.2 softwar, by ESRI, was used to create the mosaic, RGB composition, segmentation and classification of maps features and their preparation.

\section{Methodological procedures}

The Red, Green and Blue (RGB) composition of images was obtained according to wavelength, $\mathrm{R}$ with $625-695 \mathrm{~nm}, \mathrm{G}$ with $520-600 \mathrm{~nm}$ and $\mathrm{B}$ at $450-520 \mathrm{~nm}$. Images classification and interpretation process was manually performed, followed by verification by visual interpretation to generate map of land use in scale 1:100,000.

Classes considered were, degraded area by mining, burned area, rural construction (house, hangar and corral), urban influence, permanent farming, semi-perennial farming, temporary farming, water masses, pastures, silviculture, riparian vegetation and natural vegetation. Names of the land use classes and their respective colors on maps follow the technical manual of land use of the Brazilian Institute of Geography and Statistics (Instituto Brasileiro de Geografia e Estatística) (IBGE), (2006).

Three visits took place in the study area during February 2013 to take photographic registers in order to validate features encountered in the area. To assess landscape quality, methodology proposed by Griffith (1979) was used, which adopts the indirect assessment method through visual impact, however using orbital images to assess quality, considering also naturalness and diversity.

Each identified class received a corresponding value according to landscape quality. The class with low visual quality, which corresponds to number 1, identifies mining and burnt off areas, medium low is number 2 (silviculture), medium is number 3 (rural construction, urban influence and farming). Medium-high (pasture) and high (riparian and natural vegetation) correspond to numbers 4 and 5.

The establishment of weights for land use classes was adapted according to classes found in the study area (GRIFFITH, 1979). The proposed methodology bases on visual aspect of each landscape element and considers that visual quality is high when naturalness and diversity are high too.

\section{RESULTS AND DISCUSSION}

Land use in the basin is presented in table 1, which shows classes of use and dimensions of the used area.

It appears that the bigger portion of the basin area, $86.7 \%$, is affected by human intervention, and pastures represent more than half of it.

Temporary and permanent farming are between the most represented classes of land use of the study area (Table 1). 
Table 1. Class of land use in the Queima-Pé river basin.

Tabela 1. Classe uso da terra na bacia do rio Queima- Pé.

\begin{tabular}{lcc}
\hline Classes of land use & Hectares & \% \\
\hline Mining Areas & 23.23 & 0.15 \\
Burned Areas & 100,49 & 0.64 \\
Rural construction & 211,67, & 1.35 \\
Urban Influence & 612,20 & 3.91 \\
Permanent Farming & 31.41 & 0.21 \\
Semi-perennial Farming & 2.377 .09 & 15.15 \\
Temporary Farming & $1,678.80$ & 10.70 \\
Water Masses & 91.66 & 0.59 \\
Pasture & $8,756.17$ & 55.83 \\
Silviculture & 104.44 & 0.66 \\
Riparian Vegetation & 522.22 & 3.32 \\
Natural Vegetation & $1,174.86$ & 7.49 \\
\hline Total & $15,684.24$ & 100 \\
\hline
\end{tabular}

Area occupied by natural vegetation corresponds to $7.49 \%$ of the total area of the basin and only appears in patches (Table 1). A study conducted in Santa Catarina about human impact on remaining forest fragments shows that the most affecting activities on diversity of species and vegetation structure are selective timber harvesting, pasture and rubbing of the forest sub groves, causing diminution of biodiversity and increasing risk of extinction (SEVEGNANI et al., 2012).

Table 2 shows individual values for each class of land use related to visual quality of the landscape found in the study area.

Table 2. Individual value of each class in landscape assessment.

Tabela 2. Valor individual de cada classe na valoração da paisagem.

\begin{tabular}{lcc}
\hline Class & Class & Individual Value \\
\hline 1 & Mining Areas & 1 \\
2 & Burned Area & 1 \\
3 & Rural Construction & 3 \\
4 & Urban Influence & 3 \\
5 & Permanent Farming & 3 \\
6 & Semi-perennial Farming & 3 \\
7 & Temporary Farming & 3 \\
8 & Water Masses & 5 \\
9 & Pasture & 4 \\
10 & Silviculture & 2 \\
11 & Riparian Vegetation & 5 \\
12 & Natural Vegetation & 5 \\
\hline
\end{tabular}

The mining-area class presents low landscape quality (Table 2) and according to Vieira (2011) its effects are visible, detectable in short period, since they affect landscape with disappearance of hills; presence of depressions and holes; transformation of the relief, drainage silting, soil abduction, pickling and landfills; deforestation. The effect on quality of the environment is not visible; it is detected in long period, changing quality of the surface waters.

The burned-area class was classified as low landscape visual quality (Table 2) because of extinction of all original flora and fauna. The farming-area class was classified as medium visual quality (Table 2) for presenting intermediate alteration, since cultivated plants offer little protection to soil compared to natural vegetation.

Eucalyptus plantations were defined as "sulviculture" class. This class of land use was defined as medium-low visual quality (Table 2). This classification is justified by the fact that soil remains exposed during preparation of planting until plants grow to considerable size, which takes years to happen, and during the harvesting period when grown plants disappear again. 
The riparian and natural-vegetation classes were considered with high landscape visual quality due to visual comfort provided by their scenic beauty (Table 2). According to Soares et al. (2013), in these assessed elements, naturalness and diversity are in evidence as the two most important indicators for landscape visual quality, represented by natural elements like vegetation, hills, natural ponds and rivers.

Analysis of table 3 shows that medium visual quality class dominates more than $87.80 \%$ of the basin area. High visual quality class represents $11.40 \%$ of the study area, with the max quality value. The smaller land use areas have low and medium visual quality classes.

Table 3. Area of each class of the visual quality.

Tabela 3. Áreas de cada classe de qualidade visual.

\begin{tabular}{lccc}
\hline Classes & Visual Quality & Area - ha & \% \\
\hline 1 & Low & 123.72 & 0.79 \\
2 & Medium low & 104.44 & 0.67 \\
3 & Medium & $4,911.17$ & 31.31 \\
4 & Medium high & $8,756.17$ & 55.83 \\
5 & High & $1,788.74$ & 11.40 \\
\hline Total & & $15,684.24$ & 100 \\
\hline
\end{tabular}

Figure 2 shows the map of land use in the basin, where it is possible to observe that temporary and permanent farming classes are concentrated in the south region of the basin, with some isolated areas in the north. Mining areas and burned areas appear isolated in the center-south; permanent farming is observable in isolate points in the center of the basin; semi-perennial farming is concentrated in the center-south and, with isolated areas, in the center-north.

Rural constructions are spread in the whole basin area, in isolated form; riparian vegetation is concentrated along the rivers in the whole basin region; urban influence class is found in the center of the basin; pasture occurs continuously in all the perimeter of the basin with concentration in the center-north. Natural vegetation occurs in fragments, distributed in whole area and silviculture is observable in isolated form in small areas, spread in the basin.

In the water-masses class, artificial reservoirs of the rural and urban areas were included, together with natural ponds, highlighting the artificial reservoirs and natural ponds present in the basin (Figure 2). According to Estrela et al. (2010), increase of population results in increased water demand for domestic supply and food production. This factor kept making great pressure on water springs of the municipality, resulting in the construction of artificial reservoirs.

There is a stone mining company extracting basalt in the study area, which changed the landscape relief creating an enormous crater and destroying natural vegetation (Figure 2).

In the study area was detected a burned area close to Filgueira creek in the dry season, suggesting that it was started by human activities and not by natural causes (Figure 2). Corroborating to this interference, Parreira and Cabral (2011), point out that burnings are originated by natural causes or by human intervention, to clean the area, or deriving from vandalism, religious ritual and burning of domestic waste.

In the wet season, burnings occur because of natural causes, due to hits of lightings (FERRAZVICENTINI; SALGADO-LABORIAU, 1996; SALGADO-LABORIAU et al., 1997; BARBIERI et al., 2000). In the dry season, they take place by the practice to burn vegetation in order to renew plantations and clean pastures, to open and clean agricultural areas and for natural pastures regrowth (COUTINHO, 1990, 2004; MISTRY, 1998a, 1998b).

Vegetal coverage of the riparian type can be found entirely at margins of watercourses, forming ecologic corridors (Figure 2). Ecologic corridors are an efficient method to minimize negative effects on fauna and flora population from fragmentation of the original habitats (GONÇALVES et al., 2012). Urban growth of Tangará da Serra kept increasing constantly in the last years. This urban influenced area is close to the margins of Filgueira creek, which is a tributary of Queima-Pé river (Figure 2). This class is located in the far east of the basin in a peripheral area of the city.

FLORESTA, Curitiba, PR, v. 45, n. 1, p. 21 - 30, jan. / mar. 2015. 


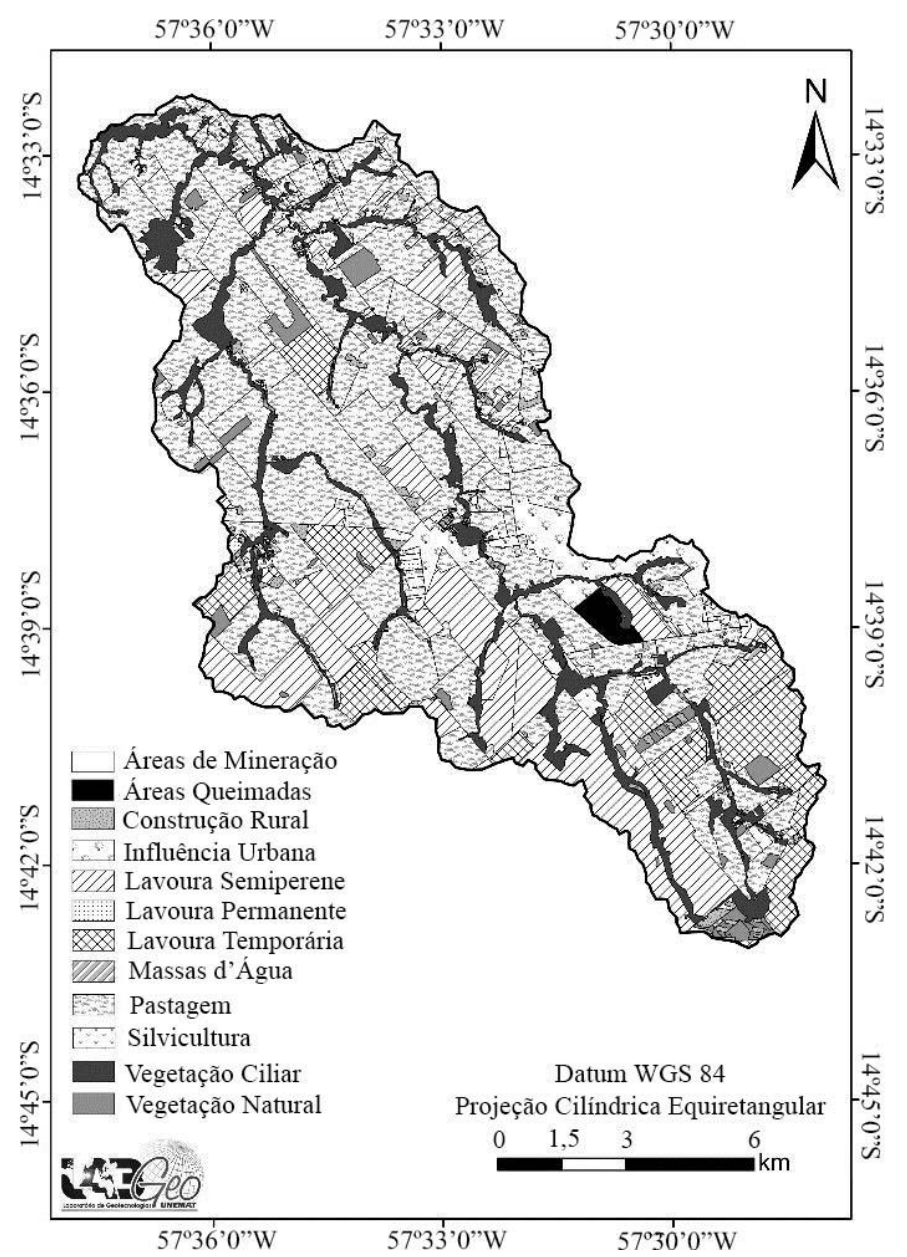

Figure 2. Map of land use in the Queima-Pé river basin.

Figura 2. Mapa de uso da terra da bacia hidrográfica do rio Queima-Pé.

Urban influence negatively affected water quality of the Filgueira creek, because absence of riparian vegetation had influence on water turbidity, with presence of urban waste, increasing total quantity of total and thermo-tolerant coliforms. Filgueira creek presented the worst index of water quality among the other tributaries of Queima-Pé River (SOUZA; NUNES, 2008).

Natural vegetation is distributed in fragmented form, far from the rivers (Figure 2). Expansion of agriculture caused rapid and intensive deforestation in the area of the basin. Figure 3 shows that the class of high visual quality occurs continuously when close to the watercourses, while it is fragmented in small areas distributed randomly in the whole basin perimeter.

Medium quality class is the most common in the land use, its extension occurs continuously from south to north of the basin. The low visual quality class presents two isolated areas and represents the smallest land use compared to the other classes.

Analysis of table 3 shows that medium quality visual class occupied by silviculture, rural construction, urban influence, farming and pastures, predominates in more than $87.80 \%$ of the basin area. This result is probably due to visual diversity and naturalness, favorable to this class, which is continuously present in the whole basin (Figure 3).

The high quality visual class occupied by riparian and natural vegetation is present in $11.40 \%$ of the study area, located along the drainage net and in isolated areas in the basin (Table 3), with maximum quality value. 


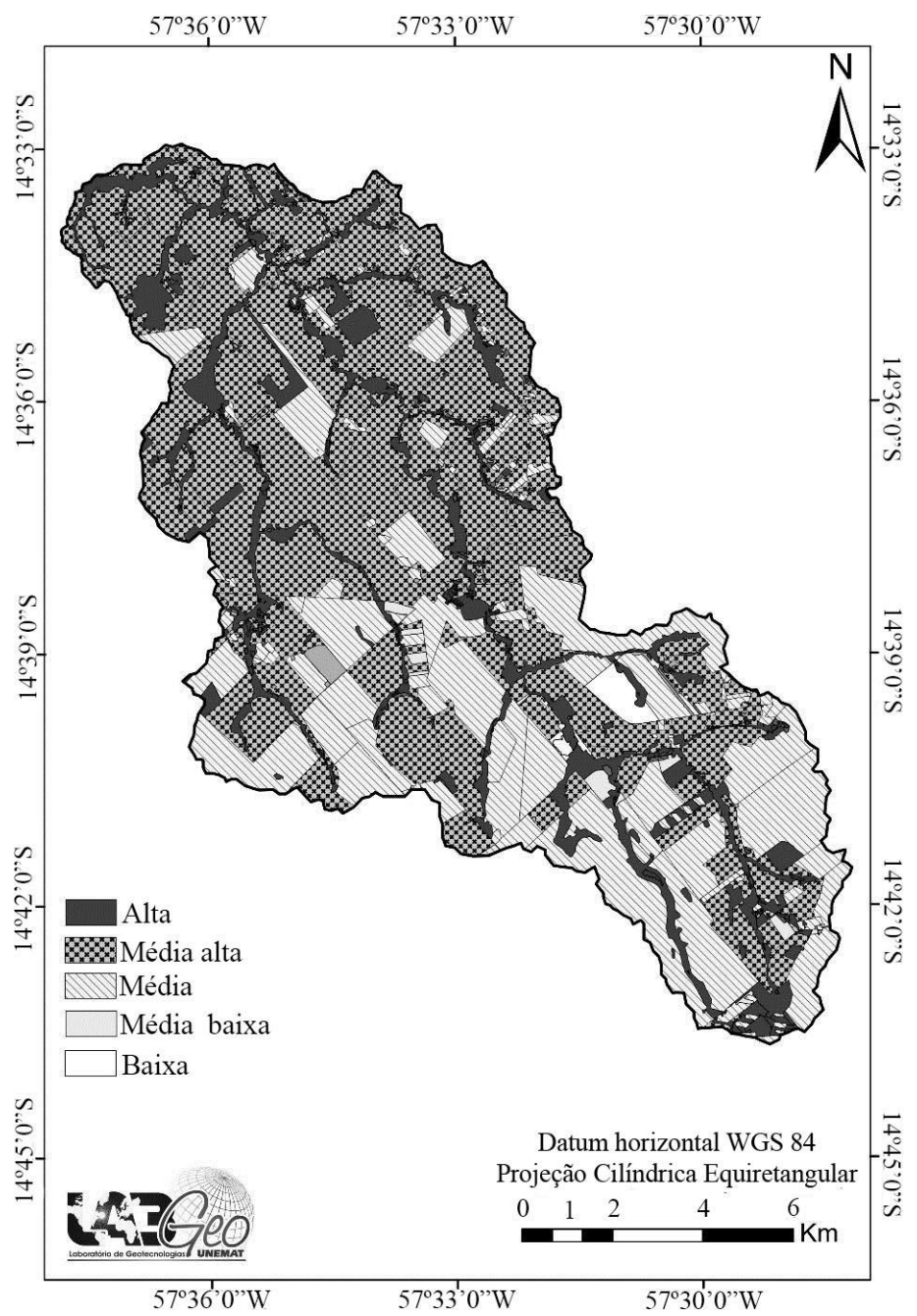

Figura 3. Mapa de qualidade visual da bacia hidrográfica do Rio Queima-Pé.

Figure 3. Map of visual quality of the Queima-Pé river.

Areas with high visual quality shall be treated as of great natural and cultural importance, and of great priority too, both for its planning and development and for its protection, because are very rich in terms of landscaping (LANDOVSKY et al., 2006).

The smaller areas of land use are located in the low visual quality class, with $0.79 \%$ of the total area, corresponding to degraded areas with mining and burnings (Table 3), distributed in the center of the basin (Figure 3). Areas with low visual quality are consequence of strong human influence.

\section{CONCLUSIONS}

- The use of GeoEye satellite images allowed identifying several classes of land use in detail, with particular mention of pasture, which occupies more than half of the total basin area.

- The analysis of quality of the basin shows that the high visual quality class, composed by riparian and natural vegetation, is one of the smallest identified classes, consequence of the occupation process of the basin by human intervention, since silviculture areas, rural construction, urban influence, farming and pasture are predominant and form the medium visual quality class.

- It is necessary, keeping these results as a base, to institute politics of territory management in the basin to avoid that visual quality of the landscape, which is now classified as medium, turns into low visual quality class. 


\section{AKNOWLEDGEMENTS}

The authors would like to thank CAPES, for supporting with master degree fellowships, one of them linked to the research project "Modelagem de indicadores ambientais para a definição de áreas prioritárias e estratégicas à recuperação de áreas degradadas da região sudoeste de Mato Grosso, MT".

This project is linked to the sub-net of social, environmental and technological studies for the productive system of the southeastern region of Mato Grosso - REDE ASA, financed by the Public Notice MCT/CNPq/FNDCT/FAPs/MEC/CAPES/PRO-CENTRO-OESTE No 031/2010.

\section{REFERENCES}

BARBIERI, M.; SALGADO-LABORIAU, M. L.; SUGUIO, K. Paleovegetation and paleoclimate of "Vereda de Águas Emendadas", Central Brazil. Journal of South American Earth Sciences, Cidade do México, v. 13, p. 241 - 254, 2000.

BERTRAND, G. Paisagem e geografia física global: esboço metodológico. Caderno de Ciências da Terra, n. 13, p. 1 - 27, 1971.

BRASIL. Ministério das Minas e Energia. Secretaria- Geral. Projeto RADAMBRASIL. Folha SD 21 Cuiabá; geologia, geomorfologia, pedologia, vegetação e uso potencial da terra. Rio de Janeiro, 1982. 520 p.

BRASIL. Plano de Conservação da Bacia do Alto Paraguai - PCBAP (Projeto Pantanal). Diagnóstico dos meios físico e biótico. Ministério do Meio Ambiente. Brasília: PNMA, 1997. v. 2. 179 p.

COUTINHO, L. M. Fire in the ecology of the Brazilian cerrado. In: Fire in the tropical biota. Ed. J.G. Goldammer. New York: Springer-Verlag, 1990. Cap. 6, p. 82 - 105.

COUTINHO, L. M. Cerrado. Disponível em: < http://www.ecologia.ib.usp.br/cerrado/> Acesso em: 15/07/2004.

DALlACORT, R.; MARTINS, J. A.; INOUE, M. H.; FREITAS, P. S. L.; KRAUSE, W. Aptidão agroclimática do pinhão manso na região de Tangará da Serra, MT. Revista Ciência Agronômica, Fortaleza, v. 41, n. 3, p. 373 - 379, 2010.

ESTRELA, C. C.; TAVARES, V. E. Q.; TIMM, L. C.; REISSER JÚNIOR, C.; MATTOS, M. L. T.; PEREIRA, G. C.; VENZKE, C. D. Caracterização das fontes de captação de água utilizadas para irrigação na cadeia produtiva de morangos, no município de Turuçu, RS. Revista Brasileira de Agrociência, Pelotas, v. 16, n. 1 - 4, p. 143 - 147, 2010.

FERRAZ-VICENTINI, K. R.; SALGADO-LABORIAU, M. L. Palynological analysis of a palm swamp in Central Brasil. Journal of South American Earth Sciences, Cidade do México, v. 9, n. 3 - 4, p. 207 219, 1996.

GOMES, H. B.; JÚNIOR, R. S. S.; PACI, F. T. DE; LIMA, D. K. C.; CASTRO, P. H. P.; SANTOS, F. B.; CABRAL, S. L.; FERREIRA, R. A. Mapeamento temático da cobertura vegetal na microrregião do sertão do São Francisco Alagoano, utilizando imagens TM Landsat 5. Revista Brasileira de Geografia Física, Recife, 5, n. 5, p. 1121 - 1132, 2012.

GONÇALVES, A. B.; MARCATTI, G. E.; RIBEIRO, C. A. A. S.; SOARES, V. P.; MEIRA NETO, J. A. A.; LEITE, H. G.; GLERIANI, J. M.; LANA, V. M. Mapeamento das áreas de preservação permanente e identificação dos conflitos de uso da terra na sub-bacia hidrográfica do rio Camapuã/ Brumado. Revista Árvore, Viçosa, v. 36, n. 4, p. 759 - 766, 2012.

GRIFFITH, J. J. Análise dos recursos visuais do parque da Serra da Canastra. Brasil Florestal, n. 40, p. $13-21,1979$.

INSTITUTO BRASILEIRO DE GEOGRAFIA E ESTATÍSTICA (IBGE). Manual Técnico de Uso da Terra. 2 ed. Rio de Janeiro, n. 7, 2006. 91 p.

INSTITUTO NACIONAL DE PESQUISAS ESPACIAIS (INPE). Processamento dos dados SRTM. São José dos Campos, 2010. 79 p. 
LANDOVSKY, G. S.; BATISTA, D. B.; ARAKI, H. Análise da qualidade visual da paisagem da região de Tibagi, PR, aplicando o sensoriamento remoto. Revista Brasileira Engenharia Agrícola e Ambiental, Campina Grande, v. 10, n. 1, p. 188 - 195, 2006.

LIMA, E. C.; SANQUENTTA, C. R.; KIRCHNER, F. F.; FERRETTI, E. R. Qualidade de paisagem: estudo de caso na floresta ombrófila mista. Floresta, Curitiba, v. 34, n. 1, p. 45 - 56, 2004.

MISTRY, J. Fire in the cerrado (savannas) of Brazil: an ecological review. Progress in Physical Geography, Road London, v. 22, n. 4, p. 425 - 448, 1998a.

MISTRY, J. Decision-making for fire use among farmers in savannas: an exploratory study in the Distrito Federal, central Brazil. Journal of environmental Management, Washington, v. 54, p. 321 - 334, 1998b.

OLIVEIRA, M. C. Paisagem, meio ambiente e planejamento. Revista do Instituto Geológico, São Paulo, v. 4, n. 1, p. $67-78,1983$.

PARREIRA, R. R. P.; CABRAL, I. L. L. Agentes causadores das queimadas no parque nacional de Chapada dos Guimarães - MT. Revista Geográfica da América Central, Costa Rica, v. 47, n. 2, p. 1 - 17, 2011.

PÉRICO, E.; CEMIN, G. Caracterização da paisagem do município de Arvorezinha, RS, com ênfase na dinâmica dos fragmentos florestais, por meio de sistemas de informações geográficas (SIGs). Scientia Forestalis, Piracicaba, v. 1, n. 70, p. 9 - 21, 2006.

SALGADO-LABORIAU, M. L.; CASSETI, V.; FERRAZ-VICENTINI, K. R.; MARTIN, L.; SOUBIÉS, F.; SUGUIO, K.; TURCQ, B. Late quaternary vegetational and climatic changes in cerrado and palm swamp from Central Brazil. Palaeogeography, Palaeoclimatology, Paleoecology, New York, v. 128, p. 215 - 226, 1997.

SEVEGNANI, L.; SILVA, T. C.; GASPER, A. L.; MEYER, L.; VERDI, M. Flora arbórea e o impacto humano nos fragmentos florestais na bacia do rio Pelotas, Santa Catarina, Brasil. REA - Revista de estudos ambientais (Online), Blumenau, v. 14, n. 1, p. 60 - 73, 2012.

SOARES, I. A.; MEDEIROS, C. S. C.; SALES FILHO, A. Análise de paisagens turísticas da praia de Jenipabu (RN) com a utilização de indicadores de qualidade visual: uma contribuição para o turismo sustentável. Caminhos de Geografia, Uberlândia, v. 14, n. 45, p. 110 - 124, 2013.

SOUZA, H. M. L.; NUNES, J. R. S. Avaliação dos parâmetros físicos químicos e bacteriológicos do córrego Filgueira pertencente a microbacia do Queima - Pé de Tangará da Serra/ MT. Engenharia Ambiental, Rio de Janeiro, v. 5, n. 2, p. 110 - 124, 2008.

VIEIRA, E. A. A (in) sustentabilidade da indústria da mineração no Brasil. Estação Científica, Macapá, v. 1, n. 2, p. $01-15,2011$.

FLORESTA, Curitiba, PR, v. 45, n. 1, p. 21 - 30, jan. / mar. 2015. 
FLORESTA, Curitiba, PR, v. 45, n. 1, p. 21 - 30, jan. / mar. 2015. Gouveia, R. G. L. de. et al. 